\title{
Аналіз онтогенетичної структури ценопопуляцій Thymus serpyllum L. Emend. Mill. Ta Thymus $x$ polessicus Klokov (Lamiaceae) в умовах Ямпільського району Сумської області (Україна)
}

\section{Лариса Пеньковська}

Сумський національний аграрний університет, Суми, Україна

Адреса для листування: e-mail: lara_penkovskaya@ukr.net

Отримано: 28.03.19; прийнято до друку: 23.04.19; опубліковано: 28.06.19

Резюме. У статті наведено характеристику рослин Thymus serpyllum та Thymus x polessicus Klokov різних онтогенетичних станів. Розраховано індекс віковості за А. А. Урановим $(\Delta)$ й індекс ефективності за Л. А. Животовським ( $\omega)$. Визначено належність кожної з досліджених ценопопуляцій до певної онтогенетичної категорії. На основі отриманих результатів зроблено висновки про онтогенетичну структуру ценопопуляцій T. serpyllum і Th. polessicus в умовах Ямпільського району Сумської області. Повну комплексну оцінку особливостей онтогенетичної структури досліджуваних популяцій, проведено з використанням спеціалізованих програмних комплексів та загальноприйнятих методичних підходів, що показало, що найбільшою константністю вирізняються генеративні рослини, наявні в усіх досліджуваних ценопопуляціях. За співвідношенням індексу віковості й індексу ефективності (величин $\Delta / \omega)$ визначено, що більшість ценопопуляцій Th. serpyllum та Th. polessicus належать до категорії старіючих. Установлено, що значення індексу віковості в усіх досліджуваних ценопопуляціях є більшими за 1. Усі провідні ознаки онтогенетичної структури популяцій Th. serpyllum i Th. polessicus в умовах Ямпільського району Сумської області вказують на те, що загалом вони мають потенціал для сталого існування в досліджуваному регіоні. Однак їх самопідтримання відбувається з різною успішністю. Здебільшого формування популяцій досліджуваних видів $є$ ускладненим під наметом соснового лісу (популяції $є$ неповними за представленістю різних онтогенетичних станів: у них наявні лише генеративні рослини). Повною за онтогенетичною структурою є лише популяція, що сформувалася в умовах угруповання Elytrigioso (repenae)-thymosum (serpyllae). У результаті радикальних змін у природних екосистемах спостерігаємо зменшення популяцій багатьох видів, що спонукає нас знайти напрями та способи регулювання механізмів розвитку природних фітоценозів. Перспективою подальших наукових досліджень $є$ застосування до досліджуваних ценопопуляцій морфометричного та віталітетного аналізу. Це уможливить оцінку морфологічних параметрів рівня життєвості особин досліджуваних видів.

Ключові слова: онтогенетична структура, ценопопуляція, Thymus serpyllum, Thymus polessicus.

\section{Analysis of Ontogenic Structure of Thymus Serpyllum L. Emend. Mill. and Thymus $x$ Polessicus Klokov (Lamiaceae) Coenopopulations Under the Conditions of the Ympil District, Sumy Region (Ukraine)}

\section{Larysa Penkovska,}

Sumy National Agrarian University, Sumy, Ukraine

Correspondence: e-mail: lara_penkovskaya @ukr.net

Abstract. The paper contains the characteristics of Thymus serpyllum and Thymus polessicus plants of various ontogenic stages and their percentage in five cenopopulations. Age index by A. A. Uranov and efficiency index by L.V. Zhyvotovskii are calculated, and each cenopopulation is assigned to a certain ontogenic category. On the ground of obtained results, conclusions are made regarding considering the ontogenic structure 
of Th. serpyllum and Th. polessicus cenopopulations in the conditions of Yampil district of Sumy region. Complex assessment of the ontogenic structure of populations was conducted using a specialized software and conventional methodologies. Showed that the majority of populations are represented by plants of 3-9 ontogenic stages. Most constant are the generative and old individuals present in all investigated cenopopulations. Based on the ratio of the age index and the efficiency index (values of $\Delta / \omega$ ), it was determined that majority cenopopulations was ageing. The value of the age index (by the method of I.M. Kovalenko [12]) is bigger than 1 in all investigated cenopopulations, suggesting the prevalence of degradation processes. According to the classification of T. O. Rabotnov, all investigated populations belong to the category of «normal». All main characteristics of Th. serpyllum and Th. polessicus populations indicate their potential for sustainable existence in the study region. However, their viability appears to be different, with the most evident imitations being faced by the populations under the pine forest canopy (populations are incomplete as to the presence of various ontogenetic states). In contrast the population growth in Elytrigioso (repenae)-thymosum (serpyllae) is community distinguished by the most complete ontogenic structure. As a result of radical changes in natural ecosystems, there is a decrease in the populations of many species, which prompts us to find directions and ways of regulating the mechanisms of development of natural phytocenoses. As a promising scientific direction, the application of the morphometric and vital analyzes of the investigated cenopopulations will allow to evaluate the morphological parameters and survival rates of the individuals of Th. serpyllum and Th. polessicus in the studied area.

Key words: ontogenic structure, cenopopulation, Thymus serpyllum, Thymus polessicus.

\section{Вступ}

Народна (традиційна) медицина України використовує як сировину понад тисячу видів судинних рослин. Такі масштаби застосування фіторесурсів зумовили те, що проблема збереження й раціонального використання лікарських рослин набула значної атуальності. Окрім того, сучасні проблеми використання лікарських рослин також зумовлені обмеженим ресурсним потенціалом багатьох цінних видів $[1,2]$. Для сьогодення залишається невирішеним питання наукового обгрунтування перспектив невиснажливого користування лікарськими фіторесурсами й збереження раритетних компонентів як для окремих регіонів, так і для України в цілому [3]. Особливо це стосується популяцій, які надмірно експлуатуються.

В Україні як на побутовому рівні, так і у фармацевтичній галузі високим попитом i популярністю користується сировина рослин, які є представниками роду чебрець (Thymus L.). Ці види - джерело цінних ефірних олій для фармацевтичної, парфумерної, харчової промисловості, більшість із них - хороші медоноси [2].

Окрім практичного значення, зумовленого господарським використанням сировини деяких видів цього роду, дослідження представників роду Thymus має i широкий теоретичний інтерес, бо цей рід - один із найбільших і таксономічно складних у родині Lamiaceae Martinov [4]. Саме труднощі в систематиці робить його особливо привабливим для вивчення, оскільки передбачає відхилення від нормального ходу еволюційного процесу й видоутворення. 3'ясування ж причин відхилень розширює уявлення про сутність цих процесів, що становлять одну 3 головних проблем біології [5].

Аналіз літературних даних засвідчив, що вивчення різних аспектів роду Thymus розкрито в досить великій кількості робіт. Зокрема, комплексний аналіз біоморфологічних, екологічних, фітоценотичних та ресурсних особивостей дикорослих видів роду Thymus на території України представлено в дослідженнях В. М. Мінарченко [6]; Л. А. Глущенко [7]; Л. М. Сивоглаз [7]. Характеристику морфологічних ознак, систематику й таксономічні проблеми представників роду Thymus розкриває у своїх роботах В. О. Начичко [8, 9]. Аналіз біоморфологічних особливостей деяких представників роду Thymus виконано в працях М. В. Казакова [10] та К. Є. Гогіна [11].

Більшість дослідників роду Thymus зазвичай пояснюють підвищену мінливість міжвидовою гибридизацією й незавершеністю процесу видоутворення в низці груп. Ці судження, як і опис морфологічних особливостей рослин, грунтуються на вивченні та зіставленні численних гербарних зразків, рідше - на загальних спостереженнях за рослинами в природі [11].

Водночас до цього часу рід Thymus ще $\epsilon$ малоохопленим популяційними дослідженнями, у т. ч. виявленням онтогенетичних характерристик. Такі дослідження важливі й необхідні, тому як стале та довготривале існування популяцій у різних місцезростаннях, а разом 3 тим і ступінь їх перспективності як джерела лікарської сировини часто значною мірою визначаються саме онтогенетичною структурою. Вона, відображаючи співвідношення в складі популяцій рослин різних онтогенетичних станів, $€$ важливою інтегральною характеристикою, що надає інформацію про 
Аналіз онтогенетичної структури ценопопуляцій Thymus serpyllum L. Emend. Mill. ma Thymиs $x$ polessicus Klokov (Lamiaceae) в умовах Ямпільського району Сумської області (Україна)

особливості протікання індивідуального розвитку рослин i його успішність [12]. Цінність та інформативність аналізу онтогенетичної структури полягає в тому, що за його результатами можна проаналізувати стан популяції не лише на час досліджень, але й охарактеризувати іiі розвиток у майбутньому [13].

До регіонів України, де представники роду Thymus досить широко представлені в складі рослинного покриву та активно заготовляються місцевим населенням, однак не охоплені ресурсними дослідженнями й популяційним аналізом, належить Ямпільський адміністративний район Сумської області. У ньому поширено Thymus serpyllum L. emend. Mill. Окрім того, трапляються й види, які $\epsilon$ результатом його гібридизації 3 іншими представниками роду Thymus. Зокрема, це Thymus x polessicus Klokov, який розглядають як результат гібридизації Thymus serpyllum та Thymus pulegioides L.

Мета статті - з'ясувати онтогенетичні параметри популяцій Th. serpyllum i Th. $x$ polessicus у фітоценозах, які $\epsilon$ типовими для Ямпільського району Сумської області.

Для досягнення мети поставлено такі завдання:

1) для досліджуваних видів визначити характерні ознаки рослин різних онтогенетичних станів;

2) визначити частку особин різних онтогенетичних станів у ценопопуляціях, охоплених вивченням;

3) для досліджуваних ценопопуляцій визначити величини узагальнювальних онтогенетичних індексів;

4) визначити належність кожної ценопопуляції до певної категорії відповідно до класифікації Т. О. Работнова та Л. А. Животовського.

\section{Матеріали та методи досліджень}

Нами протягом 2016-2018 pр. досліджено три ценопопуляції Th. Serpyllum і дві - гібриду Th. serpyllum $x$ Th. pulegioides L. (=Thymus $x$ polessicus Klokov).

Правильність визначення рослин перевірено в Інституті ботаніки ім. М. Г. Холодного НАН України. Гербарні зразки рослин із ценопопуляцій зберігаються на кафедрі екології та ботаніки Сумського національного аграрного університету.

Популяціï Th. serpyllum сформувалися в таких фітоценозах:

- популяція (П1) - в угрупованні Pinetum (sylvestris) coryloso (avellanae)-thymosum (serpyllae) - Свеське лісництво, квартал № 79, виділ № 19;

- популяція (П2) - в угрупованні Tilieto (cordatae)-Pinetum (sylvestris) thymosum (serpyllae) - Прудищанське лісництво, квартал № 21, виділ № 1;

- популяція (П3) - в угрупованні Elytrigioso (repenae)-thymosum (serpyllae) Свеське лісництво, квартал № 72, виділ № 20.

Популяції Th. polessicus сформувалися в таких фітоценозах:

- $\quad$ популяція (П4) - в угрупованні Pinetum (sylvestris) thymosum (polessicusae) - Свеське лісництво, квартал № 73, виділ № 3;

- $\quad$ популяція (П5) - в угрупованні Tilieto (cordatae)-Pinetum (sylvestris) thymosum (polessicusae) - Свеське лісництво, квартал № 63, виділ № 2.

Визначення ознак фітоценозів, у яких сформувалися ценопопуляції Th. serpyllum i Th. polessicus, проводилося в першій декаді липня. У кожному з них на ділянках розміром 10 × 10 м здійснювали геоботанічні описи 3 дотриманням загальноприйнятих методик підходів [14]. Для 3'ясування онтогенетичної структури ценопопуляцій досліджуваного виду в межах кожного угруповання за випадковою системою розміщували 20-30 облікових площ розміром $0,5 \mathrm{~m}^{2}$. На них підраховували кількість рослин досліджуваних видів різних онтогенетичних станів.

Періодизацію онтогенезу Th. serpyllum здійснювали з урахуванням підходів, запропонованих Л. А. Жуковою [13]. Зважаючи на те, що Th. serpyllum є багаторічним моноподіально наростаючим стрижнекореневим кустарничком, належність його рослин до того чи іншого онтогенетичного стану визначали за станом верхівкового пагона та сукупності бічних пагонів, сформованих на ньому. Рослини цього виду поділялися за дев'ятьма онтогенетичними станами (рис. 1), а саме:

1. Проростки (p) - рослини висотою до $0,3-0,7$ см, у них сформований вегетативний пагін 3 одним або двома міжвузлями й характерними листочками світло-зеленого кольору.

2. Ювенільні (j) - рослини висотою від 1 до 2,5 см 3 добре сформованим вегетативним пагоном із 3-5 міжвузлями, листочки вже досягають $0,5-0,7$ см у довжину та мають більш насичений зелений колір.

3. Іматурні рослини (im) - головний пагін досягає 4 см і стелиться по поверхні грунту, починають формуватися другорядні пагони в міжвузлях. 
4. Віргінільні рослини (v) - особини, представлені вже добре сформованими напівздерев'янілими пагонами, що вкорінюються за допомогою додаткових корінців.

5. Молоді генеративні $\left(\mathrm{g}_{1}\right)$ - рослини 3 інтенсивним галуженням пагонів та початком формування генеративних структур.

6. Середньовікові генеративні рослини $\left(\mathrm{g}_{2}\right)$ - особини досягають найбільшого розвитку, головний пагін інтенсивно розгалужується та вкорінюється додатковими кореня- ми. Характерне утворення значної кількості генеративних структур і їх інтенсивне цвітіння.

7. Старі генеративні рослини $\left(\mathrm{g}_{3}\right)$ уповільнюється утворення пагонів, формування генеративних структур.

8. Субсенільні рослини (ss) - у рослин яскраво виражені процеси руйнування. Ростові процеси майже зупиняються, залишається невелика кількість листків.

9. Сенільні рослини (s) - пагони й коренева система майже повністю відмирають.
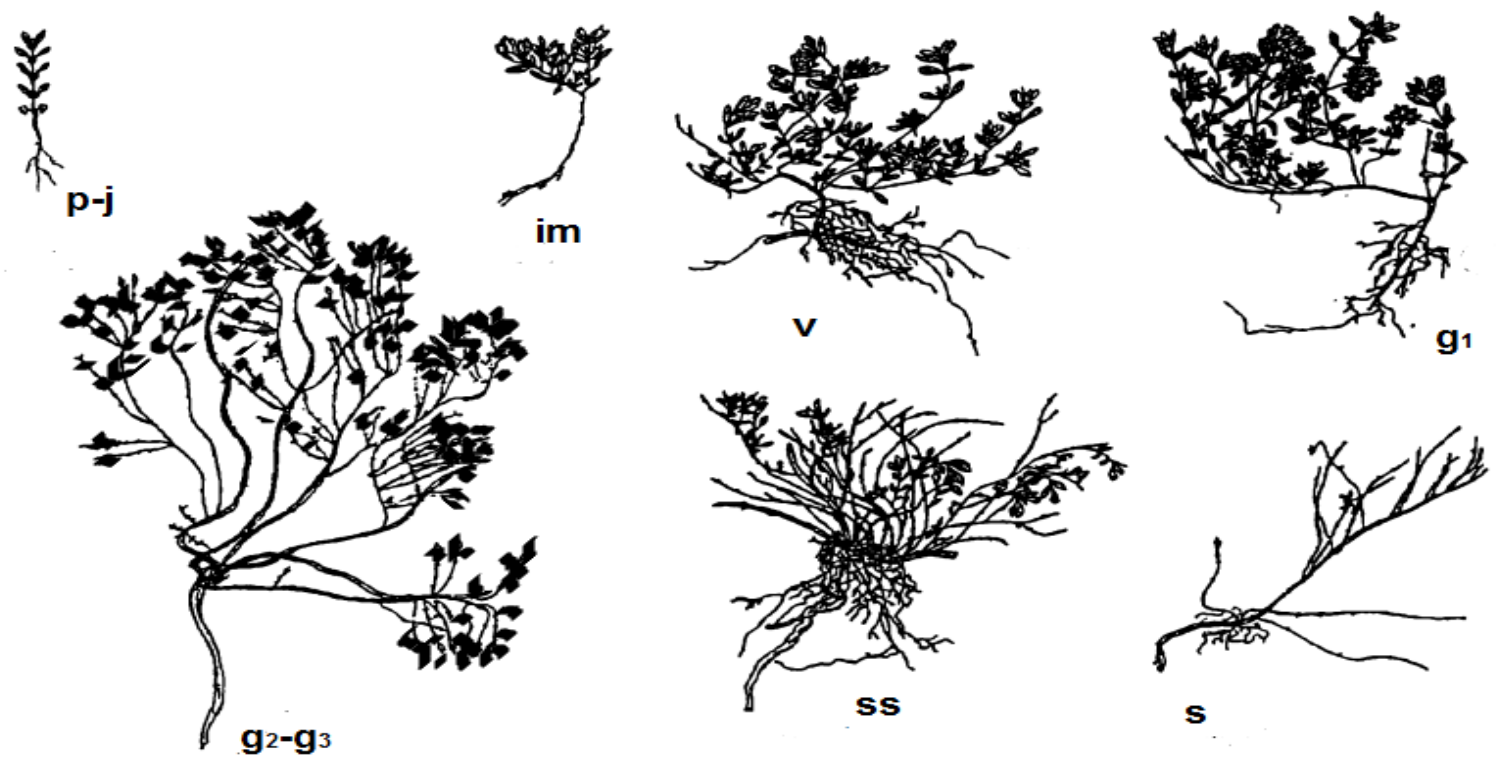

Рис. 1. Онтогенетичні стани Thymus serpyllum L. emend. Mill. (за Л. А. Жуковою, 1997)

Підходи, застосовані під час визначення онтогенетичних станів рослин Th. serpyllum, виявилися дійсними й для Th. polessicus.

Визначення онтогенетичних параметрів ценопопуляцій досліджуваних видів здійснювали за загальноприйнятими методиками Л. А. Жукової [13], Л. А. Животовського [14], Ю. А. Злобіна [15]. При цьому спочатку в складі кожної ценопопуляції визначали частку рослин різних онтогенетичних станів, а потім на основі використання некомерційного програмного комплексу ANONS, розробленого Ю. А. Злобіним, розраховували узагальнюючі онтогенетичні індекси (О. О. Уранова, Л. А. Животовського, І. М. Коваленка) визначали належність ценопопуляції до тієї чи іншої категорії $[5,13,15,16,17]$.

\section{Результати та обговорення}

Усі досліджувані популяції Th. polessicus виявилися неповними за представленістю рослин різних онтогенетичних станів (табл. 1).
У популяції 3 угруповання Tilieto (cordatae)-Pinetum (sylvestris) thymosum (polessicusae) відсутні субсенільні та сенільні рослини, а в угрупованні Pinetum (sylvestris) thymosum (polessicusae) - ще й рослини всіх догенеративних станів. У популяцій Th. serpyllum 3 угруповань Pinetum (sylvestris) coryloso (avellanae)-thymosum (serpyllae) i Tilieto (cordatae)-Pinetum (sylvestris) thymosum (serpyllae) також представлені вийнятково генеративні рослини. У $T$. serpyllum лише ценопопуляція 3 угруповання Elytrigioso (repenae)-thymosum (serpyllae) виявилася повною за онтогенетичною структурою, а в іiі складі представлено рослини всіх дев'яти онтогенетичних станів (рис. 2).

Позитивним $\epsilon$ те, що в усіх досліджуваних популяціях обох видів наявні всі групи генеративних рослин $\left(\mathrm{g}_{1}, \mathrm{~g}_{2}, \mathrm{~g}_{3}\right)$. При цьому значною $\epsilon$ питома вага представників середньовікового генеративного (у межах 24,5$30,0 \%)$ і старого генеративного (44,6-63,2 \%) станів. Відповідно, усі досліджувані 
Аналіз онтогенетичної структури ценопопуляцій Thymus serpyllum L. Emend. Mill. ma Thymиs $x$ polessicus Klokov (Lamiaceаe) в умовах Ямпільського району Сумської області (Україна)

Таблиия 1

Онтогенетична структура ценопопуляцій Thymus serpyllum та Thymus $x$ polessicus

\begin{tabular}{|c|c|c|c|c|c|c|c|c|c|}
\hline \multirow{2}{*}{$\begin{array}{c}\text { Угруповання, у яких } \\
\text { представлені } \\
\text { ценопопуляції та умовне } \\
\text { позначення }\end{array}$} & \multicolumn{9}{|c|}{ Частка (\%) особин різних онтогенетичних станів } \\
\hline & $\mathbf{p}$ & $\mathbf{j}$ & im & $\mathbf{v}$ & $\mathbf{g}_{1}$ & $\mathbf{g}_{2}$ & $\mathbf{g}_{3}$ & ss & $\mathbf{s}$ \\
\hline \multicolumn{10}{|c|}{ Thymus serpyllum } \\
\hline $\begin{array}{c}\text { Pinetum (sylvestris) coryloso } \\
\text { (avellanae)-thymosum (serpyllae) } \\
\text { (П1) }\end{array}$ & 0,0 & 0,0 & 0,0 & 0,0 & 6,8 & 30,0 & 63,2 & 0,0 & 0,0 \\
\hline $\begin{array}{c}\text { Tilieto (cordatae)-Pinetum } \\
\text { (sylvestris) thymosum (serpyllae) } \\
\text { (П2) }\end{array}$ & 0,0 & 0,0 & 0,0 & 0,0 & 18,0 & 30,0 & 52,0 & 0,0 & 0,0 \\
\hline $\begin{array}{c}\text { Elytrigioso (repenae)-thymosum } \\
(\text { serpyllae })(\Pi 3)\end{array}$ & 14,7 & 0,6 & 1,2 & 2,6 & 8,2 & 25,8 & 44,6 & 0,9 & 1,5 \\
\hline \multicolumn{10}{|c|}{ Thymus $x$ polessicus } \\
\hline $\begin{array}{c}\text { Pinetum (sylvestris) thymosum } \\
\text { (polessicusae) (П4) }\end{array}$ & 0,0 & 0,0 & 0,0 & 0,0 & 15,3 & 30,1 & 54,6 & 0,0 & 0,0 \\
\hline $\begin{array}{c}\text { Tilieto (cordatae) }- \text { Pinetum } \\
\text { (sylvestris) thymosum } \\
\text { (polessicusae) }(\Pi 5)\end{array}$ & 7,6 & 1,8 & 2,8 & 3,7 & 7,4 & 24,5 & 52,3 & 0,0 & 0,0 \\
\hline
\end{tabular}

популяції вирізняються досить високими значеннями індексу генеративності. У популяцій Th. serpyllum він варіює в межах 78,6-100,0 \%, а в Th. polessicus - від 84,5 до 100 \% (табл. 2). Максимально можливі показники індексу генеративності (100\%) зареєстровані в Th. serpyllum в угрупованнях Pinetum (sylvestris) coryloso (avellanae)- thymosum (serpyllae) та Tilieto (cordatae)Pinetum (sylvestris) thymosum (serpyllae), а в Th. polessicus - в угрупованні Pinetum (sylvestris) thymosum (polessicusae).

За розподілом рослин за різними онтогенетичними станами спектри досліджуваних ценопопуляцій обох видів належать до головних. Однак переважання в

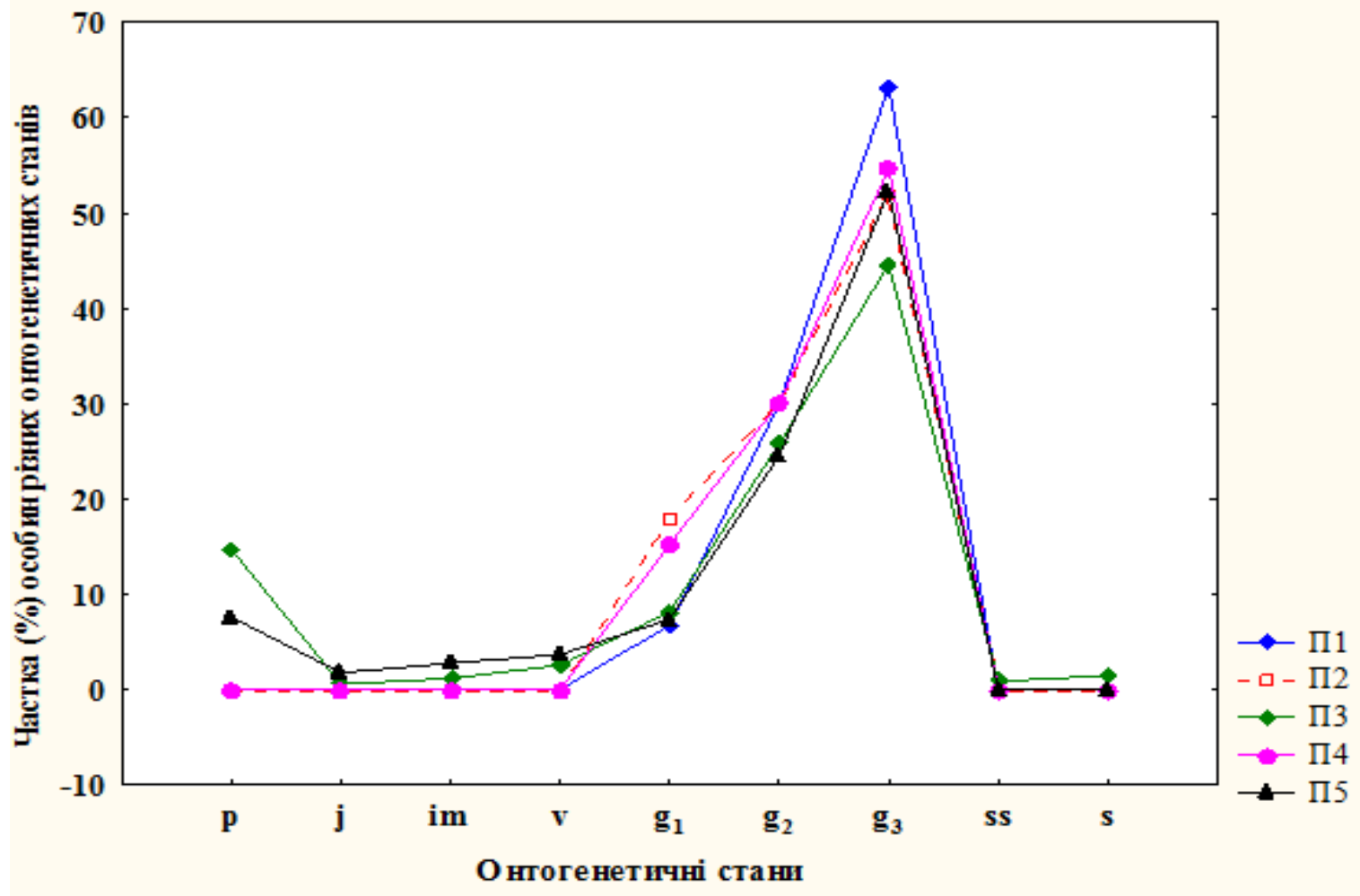

Рис. 2. Онтогенетична структура станів ценопопулящій Thyтиs serpyllum ma Thymus $x$ polessicus 
Онтогенетичні індекси ценопопуляцій Thymus serpyllum та Thymus $x$ polessicus

\begin{tabular}{|c|c|c|c|c|}
\hline \multirow{2}{*}{$\begin{array}{c}\text { Умовне } \\
\text { позначення } \\
\text { ценопопуляції }\end{array}$} & \multicolumn{4}{|c|}{$\begin{array}{l}\text { Значення онтогенетичних індексів } \\
\text { (за методикою І. М. Коваленко), \% }\end{array}$} \\
\hline & $\begin{array}{c}\text { індекс } \\
\text { відновлювання }\end{array}$ & $\begin{array}{c}\text { індекс } \\
\text { старіння }\end{array}$ & $\begin{array}{c}\text { індекс } \\
\text { генеративності }\end{array}$ & $\begin{array}{l}\text { індекс } \\
\text { віковості }\end{array}$ \\
\hline \multicolumn{5}{|c|}{ Thymus serpyllum } \\
\hline П1 & 0,0 & 63,3 & 100 & 6,3 \\
\hline$\Pi 2$ & 0,0 & 52,0 & 100 & 5,5 \\
\hline$\Pi 3$ & 19,1 & 47,0 & 78,6 & 2,5 \\
\hline \multicolumn{5}{|c|}{ Thymus $x$ polessicus } \\
\hline$\Pi 4$ & 0,0 & 54,6 & 100 & 5,4 \\
\hline$\Pi 5$ & 15,9 & 52,3 & 84,5 & 3,3 \\
\hline
\end{tabular}

Онтогенетичні індекси ценопопуляцій Thymus serpyllum та Thymus $x$ polessicus

Табличя 3

\begin{tabular}{|c|c|c|c|}
\hline $\begin{array}{c}\text { Умовне } \\
\text { позначення } \\
\text { ценопопуляції }\end{array}$ & $\begin{array}{l}\text { Індекс віковості } \\
\text { О. О. Уранова }(\Delta)\end{array}$ & $\begin{array}{c}\text { Індекс ефективності } \\
\text { Л. А. Животовського }(\omega)\end{array}$ & $\begin{array}{c}\text { Онтогенетичний тип } \\
\text { ценопопуляції } \\
\text { за співвідношенням } \\
\text { величин } \Delta / \omega \\
\end{array}$ \\
\hline \multicolumn{4}{|c|}{ Thymus serpyllum } \\
\hline$\Pi 1$ & 0,63 & 0,85 & старіюча \\
\hline$\Pi 2$ & 0,59 & 0,85 & старіюча \\
\hline П3 & 0,50 & 0,70 & перехідна \\
\hline \multicolumn{4}{|c|}{ Thymus x polessicus } \\
\hline$\Pi 4$ & 0,59 & 0,85 & старіюча \\
\hline П5 & 0,53 & 0,74 & старіюча \\
\hline
\end{tabular}

них частки саме старих генеративних рослин свідчить про те, що 3 часом у них можуть зрости представленість субсенільних рослин та, відповідно, проявитись ознаки, притаманні правостороннім спектрам. На це певною мірою вказують і результати розрахунків індексу старіння: усі досліджувані ценопопуляції мають досить високі значення цієї характеристики. У Th. serpyllum вони варіють у межах 47,0-63,3\%, а в Th. polessicus - від 52,3 до 54,6 \%. Загалом, найвищі значення індексу старіння зареєстровані в популяції Th. serpyllum 3 угруповання Pinetum (sylvestris) coryloso (avellanae)-thymosum (serpyllae), а найнижчі значення - в Elytrigioso (repenae)-thymosum (serpyllae). Популяції обох видів визнаються ще й відносно незначними величинами індексу відновлюваності: у Th. serpyllum - на рівні 019,1\%, у Th. polessicus - 0-15,9\%.

Популяції обох видів не проявили статистично достовірних відмінностей за значеннями індексу віковості О. О. Уранова $(\Delta)$ та індексу ефективності Л. А. Животовського $(\omega)$. У Th. serpyllum величини першого показника відповідають діапазону 0,50-0,63, а другого 0,70-0,85. У Th. polessicus значення цих індексів становлять 0,53-0,59 та 0,74-0,85 (табл. 3).
За співвідношенням величин $\Delta / \omega$ лише ценопопуляція Th. serpyllum 3 угруповання Elytrigioso (repenae)-thymosum (serpyllae) належить до категорії перехідних. Усі інші популяції обох видів репрезентують групу старіючих. Значення індексу віковості в усіх п'яти досліджуваних ценопопуляціях $\epsilon$ більшими за 1 (див. табл. 2). Це об'єктивно вказує на те, що в усіх них відновлювальні процеси за своєю вираженістю поступаються процесам старіння.

\section{Висновки}

Отже, результати проведеного аналізу засвідчили, що популяції обох видів проявили значний рівень подібності за сукупністю онтогенетичних характеристик. Найбільш схожими виявилися популяції, що формуються під наметом шпилькових лісів (П1 і П4). В умовах мішаних лісів популяція Th. polessicus (П5), порівняно $з$ популяціяєю Th. serpyllum (П2), вирізняється більш збалансованою онтогенетичною структурою. У Th. serpyllum найбільш сприятливий в аспекті забезпечення сталого та довготривалого існування, комплекс онтогенетичних ознак виявився притаманним 
Аналіз онтогенетичної структури ценопопуляцій Thymus serpyllum L. Emend. Mill. ma Thymиs $x$ polessicus Klokov (Lamiaceаe) в умовах Ямпільського району Сумської області (Україна)

популяції (П3), яка зростає не під наметом лісу, а в складі лучного угруповання.

Усі провідні ознаки популяцій Th. serpyllum i Th. polessicus в умовах Ямпільського району Сумської області вказують на те, що загалом вони мають потенціал для сталого існування в досліджуваному регіоні. Виявлені певні особливості в онтогенетичній структурі популяцій засвідчують необхідність розширення онтогенетичних досліджень цих двох видів на теренах регіону, результатами яких, зокрема, має стати з'ясування для популяцій $T h$. serpyllum i Th. polessicus параметрів еколого-ценотичного оптимуму та песисимуму, а також оцінка їх перспективності як джерела лікарської сировини.

\section{Література}

1. Коніщук, В. В.; Бобрик, І. В. Особливості збереження лікарських рослин України, Агроекологічний журнал; 2016, 2, с 79-84.

2. Мінарченко, В. М. Ресурсознавство. Лікарські рослини: Навч. метод. посіб. Фітосоціоцентр: Київ; 2004; с 71.

3. Якубенко, Б. С. Геоботаніка: методичні аспекти досліджень. Навч. посіб. Ліра: Київ: 2017; c 316 .

4. Клоков, М. В. Расообразование в роде тимьянов - Thymиs L. на територии советского Союза. Наук. Думка; Київ: 1973; с 187.

5. Гогина, Е. Е. Изменчивость и формообразование в роде Thymиs L. Ботаника; Москва: 198, с 430.

6. Глущенко, Л. А.; Мінарченко, В. М. До питання ресурсного потенціалу деяких чебреців України. Проблеми лікарського рослинництва. Матеріали наук. практ. конф., 3-5 лип. 1996. Полтава, с 23-24.
7. Глущенко, Л. А.; Сивоглаз, Л. М. Оцінка вихідного матеріалу для створення родових комплексів Thymus та Hypericum. Методологічні основи формування, ведення та використання колекиій генетичних ресурсів рослин. Матеріали доп. міжнар. симп. 2-4 жовт. 1996. Харків, с 170.

8. Начичко, В. О. Огляд систем роду Thymus L. (Labiatae Juss.). Вісник ОНУ. Серія «Біологія»; 2013, 18, c 7-21.

9. Начичко, В. О. Рід Thymus L. (Labiatae Juss.) у флорі Українських Карпат: систематика i таксономічні проблеми. Вісник Львівського університету. Серія «Біологія»; 2014, 64, с 159-169.

10. Казакова, М. В. Род Thymus L. - Тимьян, Чабрец. Флора средней полосы Европейской части России; Москва: 2006; с 440-442.

11. Гогина, Е. Е. О некоторых направлениях эволюции жизненных форм в роде Thymus L. Жизненные формы: структура, спектры, эволючия. Москва: 1981; с 46-76.

12. Смирнова, О. В. Объем счетной единицы при изучении ценопопуляций растений различных биоморф. Ценопопуляции растений. Москва: 1976; с 72-80.

13. Жукова, Л.А. Онтогенетический атлас лекарственных растений: научное издание; Йошкар-Ола: МарГУ, 1997, с 240.

14. Животовский, Л. А. Онтогенетические состояния, эффективная плотность и классификация популяций растений; Экология, 2001; с 3-7.

15. Злобин, Ю. А. Популячии редких видов растений: теоретические основы и методика изучения. Университет. кн.; Суми, 2013; с 439.

16. Злобин, Ю. А. Популячионная экология растений: современное состояние, точки роста; Университет. кн.; Суми, 2009; с 263.

17. Коваленко, I. М. Структура популяцій домінантів трав'яно-чагарничкового ярусу в лісових фітоценозах Деснянсько-Старогутського національного природного парку. Онтогенетична структура. Український Ботанічний журнал; 2005, 62, c 707-714. 